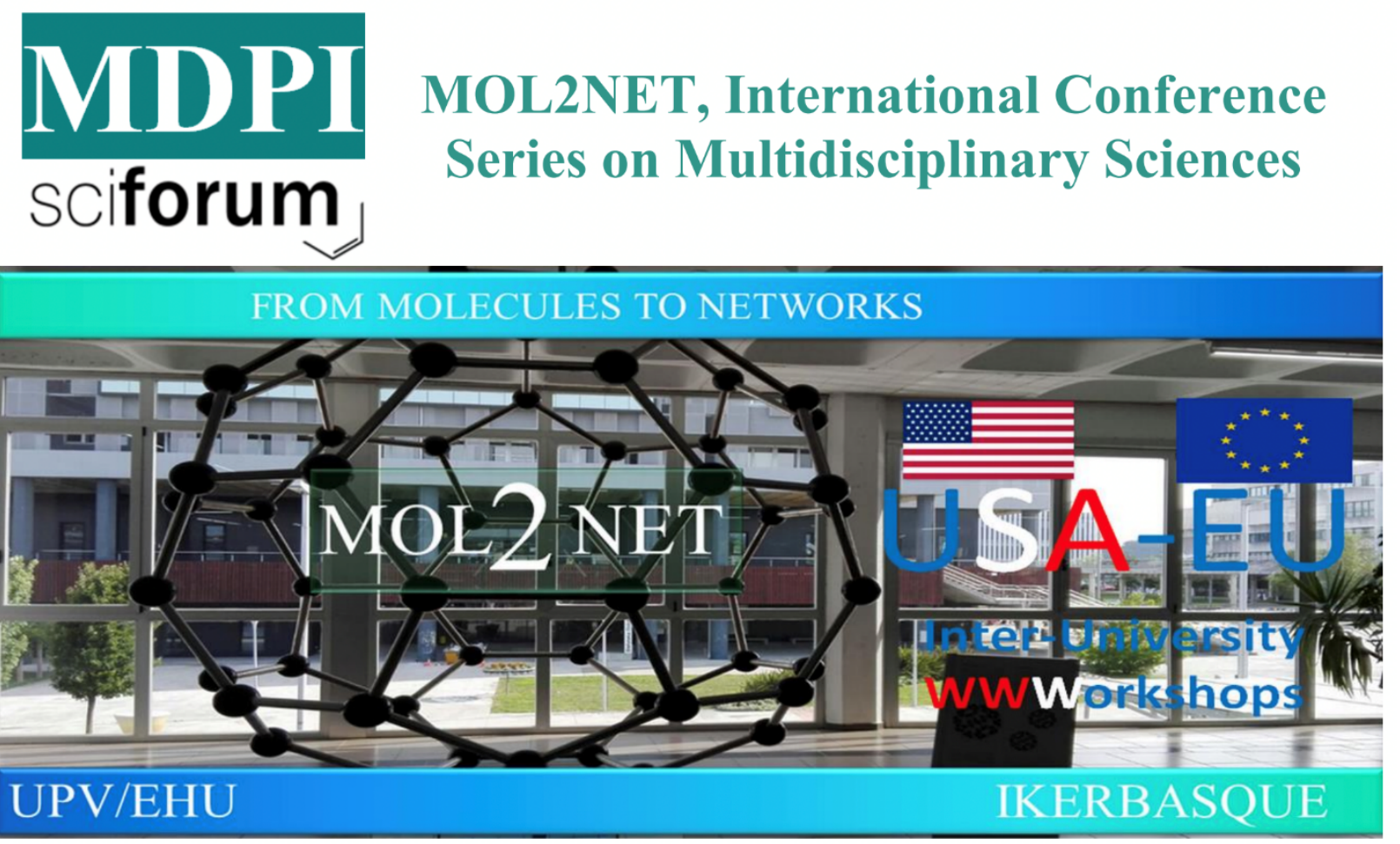

\title{
Mapping Bacterial Metabolic Network topology vs. Nanoparticle antibacterial activity
}

\author{
Bernabe Ortega-Tenezaca ${ }^{a, b, c}$
}

\author{
${ }^{a}$ RNASA-IMEDIR, Computer Science Faculty, University of A Coruna, 15071 A Coruña, Spain. \\ ${ }^{\mathrm{b}}$ Amazon State Uiversity UEA, Puyo, Pastaza, Ecuador. \\ ${ }^{\mathrm{c}}$ Center for Investigation on Technologies of Information and Communication (CITIC), \\ University of Coruña (UDC), Campus de Elviña s/n, 15071 A Coruña, Spain.
}

\begin{abstract}
The study of the bacterial metabolic structure of MNs with high resistance to the action of Nanoparticles (NPs) could help to design new NPs with specific antibacterial activity. We have used 3 numerical parameters which, in terms of graph theory, $\mathrm{N}_{\mathrm{ms}}$ represents the number of nodes, $<\mathrm{L}_{\text {ins }}>$ the total number of arrows entering a node and $\left\langle\mathrm{L}_{\text {outs }}>\right.$ is the total number of arrows leaving a node of the complex graph. From another point of view, $\mathrm{N}_{\mathrm{ms}}$ is the number of metabolites in the $\mathrm{MN}$, $<\mathrm{L}_{\text {ins }}>$ is the number of metabolites that are precursors of the query metabolite and $<\mathrm{L}_{\text {outs }}>$ is the number of metabolites that are products of a metabolic reaction with the query metabolite as a precursor. Finally, ACUs is a new parameter that represents the fusion of the 3 parameters mentioned above. This study also provides a closer look at the predictive power of the IFPTMLLOGR and IFPTML-RF models.
\end{abstract}




\section{Discussion}

In this study about the bacterial metabolic structure of MNs and the nanoparticle antibacterial activity is very important for predicted new NPs. The information of $\mathrm{N}_{\mathrm{ms}},\left\langle\mathrm{L}_{\text {ins }}>\right.$ and $\left\langle\mathrm{L}_{\text {outs }}>\right.$ are important variables to calculate a new parameter called ACUs. This variable represents the rate of anabolism-catabolism imbalance of MNs in the Sth organism. Equation (1) ACUs is as follows:

$$
\operatorname{ACU}_{\mathrm{s}}=\alpha \cdot \frac{\left(<\mathrm{L}_{\text {ins }}>-<\mathrm{L}_{\text {outs }}>\right)}{\mathrm{N}_{\mathrm{ms}}}
$$

The difference between the two indices in this case study represents the measure of the imbalance of anabolic versus catabolic metabolism in the network. The symbol $\alpha$ is 10 and is used as a scaling factor to transform the ACUs to the same scale as $\left\langle\mathrm{p}(\mathrm{f}(\mathrm{n}, \mathrm{c}, \mathrm{j}, \mathrm{j}, \mathrm{s})=1)_{\text {pred }}>\right.$ for further comparison. $\mathrm{N}_{\mathrm{ms}}$ is the number of metabolites in the MN. In the bacterial metabolic structure MNs, a low mean value $\mathrm{p}(\mathrm{f}(\mathrm{n}, \mathrm{c}, \mathrm{c}, \mathrm{j}, \mathrm{s})=1)_{\text {avg }}=<\mathrm{p}(\mathrm{f}(\mathrm{n}, \mathrm{c}, \mathrm{j}, \mathrm{s})=1)_{\text {pred }}>\left(\right.$ mean of all values of $\left.\mathrm{p}(\mathrm{f}(\mathrm{n}, \mathrm{c}, \mathrm{j}, \mathrm{s})=1)_{\text {pred }}\right)$ for the $\mathrm{s}_{\text {th }}$ bacterium against the same NP in different assays is predicted to indicate that this organism should be highly resistant to this particular NP, regardless of the assay selected. Table (1) represents the values of $\mathrm{p}\left(\mathrm{f}(\mathrm{f}(\mathrm{n}, \mathrm{c}, \mathrm{s}, \mathrm{j})=1)_{\mathrm{avg}}, \mathrm{N}_{\mathrm{ms}},<\mathrm{L}_{\text {outs }}>,<\mathrm{L}_{\text {ins }}>\right.$, and AUCs of all MNs studied. These observed and calculated average values are compared between species and/or strains susceptible to a given $\mathrm{NP}$ in a specific assay. The $\mathrm{p}(\mathrm{f}(\mathrm{n}, \mathrm{c}, \mathrm{j}, \mathrm{s})=1)_{\text {avg }}$ values are the mean value of the predicted probabilities for broad groups of bacterial species. The values of $\mathrm{p}(\mathrm{f}(\mathrm{f}(\mathrm{n}, \mathrm{c}, \mathrm{j}, \mathrm{s})=1) \mathrm{ns}$ are both the observed and predicted values for specific pairs of NPs versus MNs. See equation (2):

$$
\mathrm{p}(\mathrm{f}(\mathrm{n}, \mathrm{c}, \mathrm{j}, \mathrm{s})=1) \mathrm{ns}=\mathrm{n}(\mathrm{f}(\mathrm{n}, \mathrm{c}, \mathrm{s}, \mathrm{j})=1 / \mathrm{n}, \mathrm{s}) / \mathrm{n}(\mathrm{n}, \mathrm{s})
$$

In this equation $n(f(n, c, s, j)=1 / n, s)$ is the number of success cases. The parameter $n(n, s)$ is the total number of cases since the NPn $v s$. MNs pair has been used in preclinical trials. Two IFPTML models were used both the observed and the calculated version of $\mathrm{p}(\mathrm{f}(\mathrm{f}(\mathrm{n}, \mathrm{c}, \mathrm{c}, \mathrm{j}, \mathrm{s})=1) \mathrm{ns}$. This study also provides a closer look at the predictive power of the IFPTML-LOGR and IFPTML-RF models. Taking into account the biological significance of the ACUs and the $p(f(n, c, j, s)=1) n s$ values of the susceptibility of NP bacteria vs. the ACUs index of the MNs of all bacteria, then: ACUs $>0.5$, for MNs exhibiting unbalanced metabolism on the anabolic side. ACUs $=0$, for MNs that have a balanced anabolic-catabolic metabolism. In the range $-0.5<$ ACUs $<+0.5$, for MNs that have a nearly balanced metabolism. ACUs $<-0.5$, for MNs presenting an unbalanced metabolism on the catabolic side.

The choice of the above values is empirical and should be seen only as a practical tool for systematization/preliminary visualization of structural-functional information on NPn $v s$. MNs interaction. For systematization purposes. The Figure has been divided into four quadrants $\mathrm{Q}_{\mathrm{I}}$, QII, $\mathrm{Q}_{\text {III }}$ and $\mathrm{Q}_{\text {IV }}$ delimited by quartiles of $\mathrm{ACUs}$ and $\mathrm{p}(\mathrm{f}(\mathrm{f}(\mathrm{n}, \mathrm{c}, \mathrm{c}, \mathrm{j}, \mathrm{s})=1) \mathrm{ns}$ within the range $0-1$. The first quadrant $\left(\mathrm{Q}_{\mathrm{I}}\right)$ includes all NP-resistant bacteria $(\mathrm{p}(\mathrm{f}(\mathrm{f}(\mathrm{n}, \mathrm{c}, \mathrm{c}, \mathrm{j}, \mathrm{s})=1) \mathrm{ns}<0.5)$ with MNs unbalanced on the anabolic side (ACUs $>0.5)$. The second quadrant $\left(\mathrm{Q}_{\mathrm{II}}\right)$ includes all NP-susceptible bacteria $(\mathrm{p}(\mathrm{f}(\mathrm{f}(\mathrm{n}, \mathrm{n}, \mathrm{c}, \mathrm{j}, \mathrm{s})=1) \mathrm{ns}>0.5)$ with MNs unbalanced on the anabolic side (ACUs $>0.5)$. The third 
quadrant $\left(\mathrm{Q}_{\text {III }}\right)$ includes all NP-susceptible bacteria $(\mathrm{p}(\mathrm{f}(\mathrm{n}, \mathrm{c}, \mathrm{c}, \mathrm{j}, \mathrm{s})=1) \mathrm{ns}>0.5)$ and with MNs nearly balanced (ACUs $=$ range $0-0.5$ ). The last quadrant (QIV) includes all NP-susceptible bacteria $\left(\mathrm{p}\left(\mathrm{p}(\mathrm{f}(\mathrm{n}, \mathrm{c}, \mathrm{c}, \mathrm{j}, \mathrm{s})=1)_{\mathrm{avg}}<0.5\right)\right.$ with nearly balanced MNs (range ACUs $\left.=0-0.5\right)$. The IFPTML models used in this study can help reduce costs and time in the discovery of new NPs by including the MN structure of the target bacteria increasing the range of application of IFPTML models to design NPs against other bacterial species.

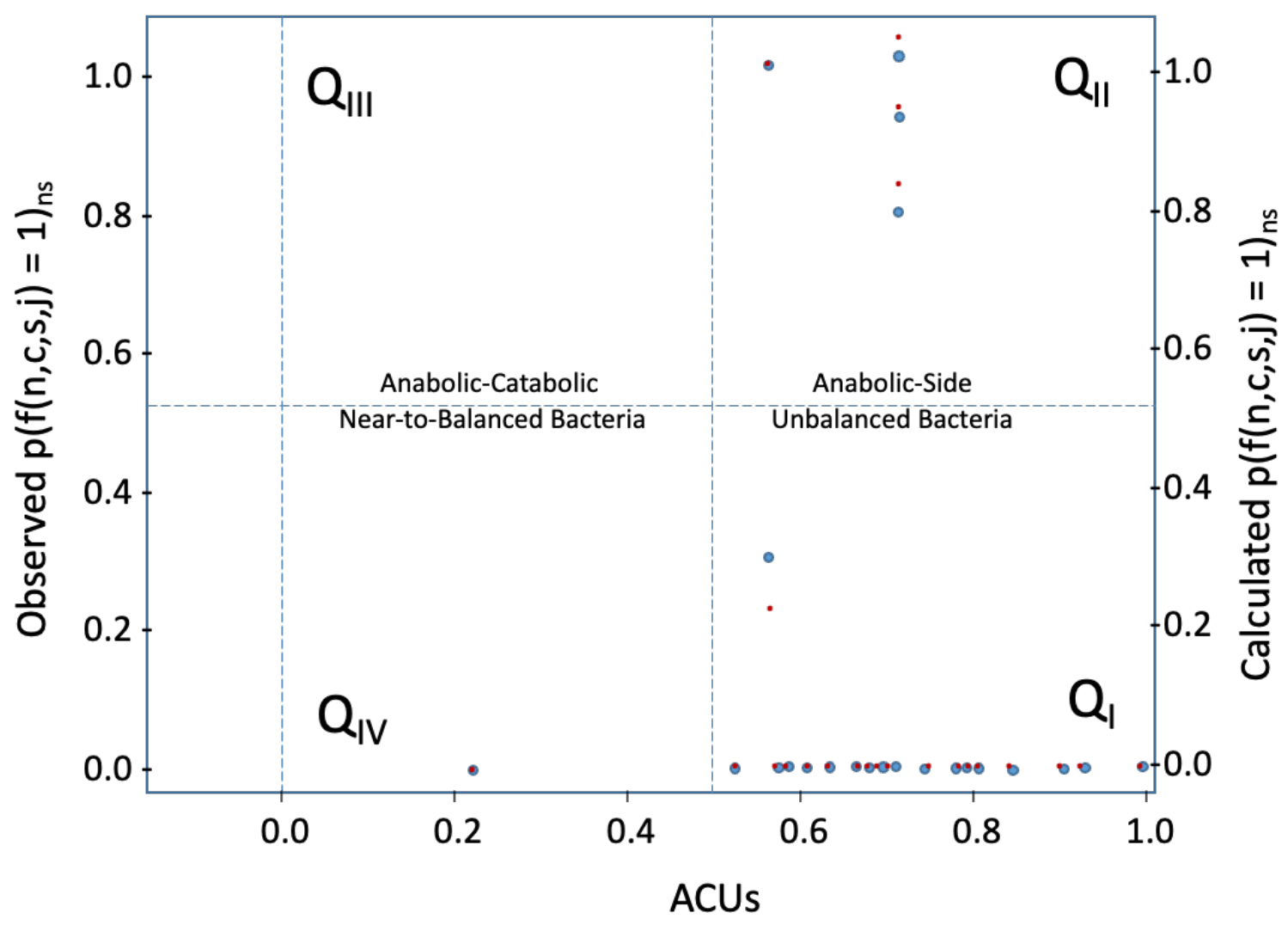




\section{REFERENCES}

1. Y. Li, X. Zhang and D. Cao, Nanoscale, 2015, 7, 2758-2769.

2. V. Brunetti, L. M. Bouchet and M. C. Strumia, Nanoscale, 2015, 7, 3808-3816.

3. H. Cai and P. Yao, Nanoscale, 2013, 5, 2892-2900.

4. F. De Angelis, A. Pujia, C. Falcone, E. Iaccino, C. Palmieri, C. Liberale, F. Mecarini, P. Candeloro, L. Luberto, A. de Laurentiis, G. Das, G. Scala and E. Di Fabrizio, Nanoscale, 2010, 2, 2230-2236.

5. F. Wang, X. Wang, L. Gao, L. Y. Meng, J. M. Xie, J. W. Xiong and Y. Luo, Nanoscale, 2019, 11, 18052-18064.

6. $\quad$ S. Ahn, S. Y. Jung, J. P. Lee, H. K. Kim and S. J. Lee, ACS nano, 2010, 4, 3753-3762.

7. O. Betzer, A. Shwartz, M. Motiei, G. Kazimirsky, I. Gispan, E. Damti, C. Brodie, G. Yadid and R. Popovtzer, ACS nano, 2014, 8, 9274-9285.

8. J. C. Hsu, P. C. Naha, K. C. Lau, P. Chhour, R. Hastings, B. F. Moon, J. M. Stein, W. R. T. Witschey, E. S. McDonald, A. D. A. Maidment and D. P. Cormode, Nanoscale, 2018, 10, 1723617248.

9. A. Nabil, M. M. Elshemy, M. Asem, M. Abdel-Motaal, H. F. Gomaa, F. Zahran, K. Uto and M. Ebara, Oxidative medicine and cellular longevity, 2020, 2020, 1362104.

10. W. P. Caron, K. P. Morgan, B. A. Zamboni and W. C. Zamboni, Clin. Cancer Res., 2013, 19, 3309-3315.

11. A. Gajewicz, Nanoscale, 2017, 9, 8435-8448.

12. K. Jagiello, M. Grzonkowska, M. Swirog, L. Ahmed, B. Rasulev, A. Avramopoulos, M. G. Papadopoulos, J. Leszczynski and T. Puzyn, Journal of nanoparticle research : an interdisciplinary forum for nanoscale science and technology, 2016, 18, 256.

13. H. Gonzalez-Diaz, S. Arrasate, A. Gomez-SanJuan, N. Sotomayor, E. Lete, L. Besada-Porto and J. M. Ruso, Current topics in medicinal chemistry, 2013, 13, 1713-1741.

14. T. Hill and P. Lewicki, Statistics: Methods and Applications, StatSoft, Inc., 1st edition edn., 2005.

15. B. Ortega-Tenezaca, V. Quevedo-Tumailli, H. Bediaga, J. Collados, S. Arrasate, G. Madariaga, C. R. Munteanu, M. Cordeiro and H. Gonzalez-Diaz, Curr Top Med Chem, 2020, DOI: $10.2174 / 1568026620666200916122616$.

16. B. Hanczar, J. Hua, C. Sima, J. Weinstein, M. Bittner and E. R. Dougherty, Bioinformatics, 2010, $26,822-830$. 